\title{
Morphology and morphometry of feline bone marrow-derived mesenchymal stem cells in culture ${ }^{1}$
}

\author{
Bruno B. Maciel ${ }^{2}$, Carmen L.K. Rebelatto ${ }^{3}$, Paulo R.S. Brofman ${ }^{3}$, Harald F.V. Brito², \\ Lia F.L. Patricio ${ }^{2}$, Marúcia A. Cruz ${ }^{4}$ and Rosangela Locatelli-Dittrich ${ }^{2 *}$
}

\begin{abstract}
Maciel B.B., Rebelatto C.L.K., Brofman P.R.S., Brito H.F.V., Patricio L.F.L., Cruz M.A. \& Locatelli-Dittrich R. 2014. Morphology and morphometry of feline bone marrowderived mesenchymal stem cells in culture. Pesquisa Veterinária Brasileira 34(11):11271134. Programa de Pós-Graduação em Ciências Veterinárias, Universidade Federal do Paraná, Setor de Ciências Agrárias, Rua dos Funcionários 1540, Juvevê, Curitiba, PR 80035-050, Brazil. E-mail: roslocdi@ufpr.br

Mesenchymal stem cells (MSC) are increasingly being proposed as a therapeutic option for treatment of a variety of different diseases in human and veterinary medicine. Stem cells have been isolated from feline bone marrow, however, very few data exist about the morphology of these cells and no data were found about the morphometry of feline bone marrow-derived MSCs (BM-MSCs). The objectives of this study were the isolation, growth evaluation, differentiation potential and characterization of feline BM-MSCs by their morphological and morphometric characteristics. In vitro differentiation assays were conducted to confirm the multipotency of feline MSC, as assessed by their ability to differentiate into three cell lineages (osteoblasts, chondrocytes, and adipocytes). To evaluate morphological and morphometric characteristics the cells are maintained in culture. Cells were observed with light microscope, with association of dyes, and they were measured at 24, 48, 72 and $120 \mathrm{~h}$ of culture (P1 and P3). The non-parametric ANOVA test for independent samples was performed and the means were compared by Tukey's test. On average, the number of mononuclear cells obtained was $12.29\left( \pm 6.05 \times 10^{6}\right)$ cells $/ \mathrm{mL}$ of bone marrow. Morphologically, BM-MSCs were long and fusiforms, and squamous with abundant cytoplasm. In the morphometric study of the cells, it was observed a significant increase in average length of cells during the first passage. The cell lengths were $106.97 \pm 38.16 \mu \mathrm{m}$ and $177.91 \pm 71.61 \mu \mathrm{m}$, respectively, at first and third passages $(24 \mathrm{~h})$. The cell widths were $30.79 \pm 16.75 \mu \mathrm{m}$ and $40.18 \pm 20.46 \mu \mathrm{m}$, respectively, at first and third passages $(24 \mathrm{~h})$. The nucleus length of the feline BM-MSCs at P1 increased from $16.28 \mu \mathrm{m}(24 \mathrm{~h})$ to $21.29 \mu \mathrm{m}(120 \mathrm{~h})$. However, at P3, the nucleus length was $26.35 \mu \mathrm{m}(24 \mathrm{~h})$ and $25.22 \mu \mathrm{m}(120 \mathrm{~h})$. This information could be important for future application and use of feline BM-MSCs.
\end{abstract}

INDEX TERMS: Feline, multipotent stem cell, stem cell isolation, cell morphometry, cell morphology.

RESUMO.- [Morfologia e morfometria das células-tronco mesenquimais isoladas de medula óssea de gato.] As células tronco mesenquimais são utilizadas na terapia de várias doenças na medicina humana e veterinária. As células tronco foram isoladas da medula óssea de gato, entretanto, existem poucos dados referentes a morfologia e não

\footnotetext{
${ }^{1}$ Received on May 21, 2014.

Accepted for publication on August 16, 2014.

${ }^{2}$ Programa de Pós-Graduação em Ciências Veterinárias, Setor de Ciências Agrárias, Universidade Federal do Paraná (UFPR), Rua dos Funcionários 1540, Juvevê, Curitiba, PR 80035-050, Brazil. *Corresponding author: roslocdi@ufpr.br
}

existem informações sobre a morfometria das células tronco isoladas da medula óssea. Os objetivos do presente estudo foram o isolamento, avaliação do crescimento, potencial de diferenciação e caracterização morfológica e morfométrica das células mesenquimais de gato isoladas de medula óssea. A diferenciação in vitro foi realizada para confirmar a

\footnotetext{
${ }^{3}$ Laboratório Experimental de Cultivo Celular, Pontifícia Universidade Católica do Paraná (PUC-PR), Rua Imaculada Conceição 1155, Curitiba, PR 80215-901.

${ }^{4}$ Clínica Veterinária “Mania de Gato”, Av. Manoel Ribas 1125, Mercês, Curitiba, PR 80810-000.
} 
multipotencialidade das células mesenquimais de gato (diferenciação em osteoblastos, condrócitos, adipócitos). As células mesenquimais foram mantidas em cultivo para avaliações morfológica e morfométrica. As células foram coradas e observadas em microscopia ótica. As mensurações foram realizadas com 24, 48, 72 e $120 \mathrm{~h}$ de cultura (primeira e terceira passagens). 0 teste não paramétrico ANOVA foi utilizado e as médias foram comparadas pelo teste de Tukey. 0 número médio de células mononucleares obtido foi de $12,29\left( \pm 6,05 \times 10^{6}\right)$ células $/ \mathrm{mL}$ de medula óssea. As células mesenquimais são longas e fusiformes, e escamosas com citoplasma abundante. No estudo morfométrico, observou-se aumento no comprimento médio das células durante a primeira passagem. As medidas de comprimento das células foram: $106,97 \pm 38,16 \mu \mathrm{m}$ e $177,91 \pm 71,61 \mu \mathrm{m}$, respectivamente, na primeira e terceira passagens (24 horas). As medidas de largura das células foram: $30,79 \pm 16,75 \mu \mathrm{m}$ e $40,18 \pm 20,46 \mu \mathrm{m}$, respectivamente, na primeira e terceira passagens ( 24 horas). O comprimento do núcleo na primeira passagem aumentou de $16,28 \mu \mathrm{m}(24 \mathrm{~h})$ para $21,29 \mu \mathrm{m}(120 \mathrm{~h})$ e na terceira passagem foi de $26,35 \mu \mathrm{m}(24 \mathrm{~h})$ para $25,22 \mu \mathrm{m}$ (120h). As informações são importantes para futuras aplicações e uso da célula mesenquimal de gato.

TERMOS DE INDEXAÇÃO: Felinos, células mesenquimais, isolamento de células mesenquimais, morfometria celular, morfologia celular.

\section{INTRODUCTION}

During the last two decades, stem cells have become recognized as a promising tool for various biomedical applications including disease modeling, drug development, and cell replacement therapies. Mesenchymal stem cells (MSC) therapy is being proposed as a therapeutic option for treatment of a variety of different diseases (Webb et al. 2011, Quimby et al. 2011,Penha et al. 2014). The stem cell field in veterinary medicine continues to evolve rapidly both experimentally and clinically (Fortier \& Travis 2011).

Bone marrow (BM) is the traditional source of MSC, and bone marrow-derived mesenchymal stem cells (BM-MSCs) have the advantages of being easily and relatively noninvasively obtained and have a greater capacity to differentiate into tissue types of the musculoskeletal system in comparison with other MSCs. Furthermore, BM-MSCs have received the most scientific attention and hence are the best characterized (Fortier \& Travis 2011). Although feline mesenchymal stem cells isolated from adipose tissue (AT) proliferated signicantly faster than BM-MSC, the isolation of AT-derived MSC currently relies on the use of the enzyme collagenase (Webb et al. 2011, Shah et al. 2013). Collagenase is an expensive reagent derived from a bacterial source, and its use in isolating AT-derived MSC is a time-consuming procedure (Shah et al. 2013). Research interests continuously exist in both the biology and potential therapeutic applications of adult stem cells from bone marrow (Zhu et al. 2008, Webb et al. 2011, Munoz et al. 2012, Penha et al. 2014).

In recent decades interest in stem cells has been growing, from both a basic biological and a therapeutic pers- pective. In response to this, studies have been developed to compare the morphology and size of mesenchymal stem cells mammalian species (Hoogduijn et al. 2013, Grzesiak et al. 2011). Morphology and morphometry of equine and canine adipose derived mesenchymal stem cells tend to be very similar, however further studies of this topic are needed (Grzesiak et al. 2011). Furthermore, the size of feline mesenchymal stem cells is of general biological interest.

Stem cells have been isolated from feline bone marrow (Martin et al. 2002, Jin et al. 2008, Kubo et al. 2009, Webb et al. 2011), however, very few data exist about the morphology of these cells and no data were found about the morphometry of feline BM-MSCs (Martin et al. 2002, Webb et al. 2011, Munoz et al. 2012).

Based on these observations, the objectives of this study were the isolation, growth, differentiation and characterization of feline BM-MSCs by their morphological and morphometric characteristics.

\section{MATERIALS AND METHODS}

The study protocol was approved by the Animal Use Ethics Committee of the Agricultural Sciences Campus of the Federal University of the State of Paraná, Southern Brazil (CEUA-SCA/UFPR number 044/2008).

Fourteen housecats (ages ranging from nine months to 10 years, seven male and seven female) were used for the study. Feline bone marrow was collected by bone marrow aspiration during osteosynthesis surgery in the Veterinary Hospital of the Federal University of Paraná (HV-UFPR) and veterinary clinics in Curitiba-PR-Brazil. No animal showed signs of concomitant disease.

Bone marrow collection. For sample collection, cats were anaesthetized with continuous infusion of propofol. Bone marrow was collected by aseptic puncture of the greater trochanter of femur or the greater tubercle of humerus with $10 \mathrm{~mL}$ syringe and 10,000 IU of heparin (Cristália, São Paulo, Brazil), and Jamshidi Bone Marrow Biopsy Needle (13 G) and catheter (14 G).

Isolation and cell culture. Samples were diluted at a ratio of 1:3 with Dulbecco's Modified Eagle's Medium (DMEM) (Gibco Invitrogen, NY, USA) and placed slowly on a $50 \mathrm{~mL}$ conical tube (TPP, Transadingen, Switzerland) containing $10 \mathrm{~mL}$ of Histopaque $1.077 \mathrm{~g} / \mathrm{mL}$ (Sigma Chemical, St Louis, USA). The tubes were centrifuged for 30 minutes at $400 \mathrm{~g}$ with minimum acceleration and no brakes. The white ring of mononuclear cells was removed using a sterile serological pipette. The mononuclear cells were washed twice with culture medium by centrifugation at $400 \mathrm{~g}$ and resuspended in DMEM supplemented with 15\% fetal bovine serum (FBS) (Gibco Invitrogen, NY, USA), penicillin (100 units/ $\mathrm{ml})$ and streptomycin $(100 \mu \mathrm{g} / \mathrm{ml})$ (Gibco Invitrogen, NY, USA). The viability and viable cell yield was determined by Trypan Blue $0.4 \%$ (Sigma Chemical) exclusion count in Neubauer's chamber before seeding the cells and at each passage.

Initial plating. Mononuclear cells were seeded in $75 \mathrm{~cm}^{2}$ culture flasks (TPP) at a density of $1 \times 10^{5}$ cells $/ \mathrm{cm}^{2}$ and maintained in mesenchymal stem cell basal medium (MSCBM) (Cambrex Bio Science, MD, USA) supplemented with 15\% fetal calf serum (Gibco $^{\mathrm{TM}}$ Invitrogen, NY, USA), penicillin (100 units $/ \mathrm{ml}$ ) and streptomycin $(100 \mu \mathrm{g} / \mathrm{ml})\left(\mathrm{Gibco}^{\mathrm{TM}}\right.$ Invitrogen, NY, USA). After incubation for $48 \mathrm{~h}$ at $37^{\circ} \mathrm{C}, 5 \% \mathrm{CO}_{2}$ and $95 \%$ humidity (Thermo Forma), the culture medium was replaced to remove non-adherent cells. The culture medium was then replaced twice a week. Feline BM-MSCs were subcultured after the culture had reached 80\%-90\% confluence. MSCs were detached with $0.25 \%$ trypsin/EDTA (Invi- 
trogenTM, NY, USA) and were replated as passage 1 cells. It was performed four passages (P1, P2, P3 and P4) to obtain a homogeneous population of mesenchymal stem cells (no contamination with hematopoietic cells).

Colony-forming unit fibroblast (CFU-F) assay. To assess the number of progenitor mesenchymal stem cells in samples, at each passage some cells were seeded in triplicate, at a concentration of 470 and 752 cells $/ \mathrm{cm}^{2}$, in $9.6 \mathrm{~cm}^{2}$ petri dishes (TPP), with $2.0 \mathrm{~mL}$ of DMEM supplemented with $15 \%$ FBS. The cells were maintained for 14 days at $37^{\circ} \mathrm{C}$ and $5 \% \mathrm{CO}_{2}$. The medium was replaced once week.

For colony staining, the cells were washed with phosphate-buffered saline (PBS) (Gibco Invitrogen, NY, USA) twice and stained with $1 \%$ crystal violet (Sigma Chemical, St Louis, USA) diluted in methanol, for $10 \mathrm{~min}$ at room temperature. The petri dishes were rinsed three times with distilled water and kept in the inverted position for drying. This protocol was adapted from Meireles \& Nardi (2003).

A group of more than 50 cells was considered as a colony. Colonies were counted under a magnifying lens (Nikon, Japan).

Cellular morphology. The cells were plated at $5 \times 10^{3}$ cells per $40 \times 11-\mathrm{mm}$ plate (TPP) in $20-30 \mu \mathrm{L}$ of culture medium onto glass coverslips for 60 minutes at $37^{\circ} \mathrm{C}$ and $5 \% \mathrm{CO}_{2}$ to cellular adherence. After that, it was added $2 \mathrm{~mL}$ of culture medium on each plate, which was maintained for $24,48,72$ and $120 \mathrm{~h}$. At the indicated times, the culture medium was removed and the coverslips were stained with Wright's stain and mounted with Entellan (Sigma Chemical, St Louis, USA) on glass slides.

Fifty cells at P1 and P3, from the same animal, were morphologically evaluated. We used the program Motic Image Plus 2.0 (Motic China Group) to measure length and width of the cells and their nuclei. The non-parametric ANOVA test for independent samples was performed and the means were compared by Tukey's test.

Differentiation of BM-MSC. The in vitro differentiation of feline BM-MSCs was evaluated in triplicates by culturing cells from passage 3-4 in a commercial media for adipogenesis (StemPro ${ }^{\circledR}$ Osteogenic Differentiation Basal Medium, Gibco ${ }^{\circledR}$ Invitrogen, NY, USA), osteogenesis (StemPro ${ }^{\circledR}$ Adipogenic Differentiation Basal Medium, Gibco ${ }^{\circledR}$ Invitrogen, NY, USA), and chondrogenesis (StemPro $^{\circledR}$ Chondrogenic Differentiation Basal Medium, Gibco ${ }^{\circledR}$ Invitrogen, NY, USA) using previously published protocols (Rebelatto et al. 2008). Control cells were cultured in DMEM with 15\% FBS for the same period of time. Media change was carried out every three days.

To promote osteogenic and adipogenic differentiation $20 \times 10^{3}$ cells were seeded on glass coverslips (Sartsted, NC, USA) in 24-well plates (TPP). When the cell confluence was approximately $80 \%$, the induced medium was added and changed every three days during 21 days, when the cells were stained (Jaiswal et al. 2000).

To assess the intracellular accumulation of neutral lipids, after adipogenic differentiation, cells were stained with oil red 0 (Sigma-Aldrich Corp, MO, USA). Cells were treated with Bouin's fixative (Biotec, PR, Brazil) for $10 \mathrm{~min}$ at room temperature, washed twice with $70 \%$ ethanol (Biotec, PR, Brazil) and once with ultrapure water (Milli-Q, Millipore, USA), and incubated for 10 min with filtered $0.5 \%$ oil red 0 solution prepared in $60 \%$ isopropanol. Hematoxilin-eosin (Biotec, PR, Brazil) was used to counterstain (Meirelles et al. 2006).

After osteogenic differentiation, induced monolayers were fixed for 10 min in Bouin's fixative and washed twice with 70\% ethanol and once with Milliq water. Monolayers were then incubated for 15 min with Alizarin Red S at pH 4.1 (Fluka Chemie, Buchs, $\mathrm{UK}$ ) at room temperature to evaluate the mineralized matrix (Tsai et al. 2009).
To promote chondrogenic differentiation, cells were grown in micromass culture (Johnstone et al. 1998). Briefly, $2 \times 10^{5}$ cells in $0.5 \mathrm{~mL}$ of DMEM were centrifuged at $300 \mathrm{~g}$ for $10 \mathrm{~min}$ in a $15 \mathrm{~mL}$ polypropylene tube to form a pellet. Without disturbing the pellet, cells were cultured for 21 days in an induced media, which was change every three days. On day 21, cell aggregates were fixed in $10 \%$ formaldehyde (Sigma-Aldrich Corp, MO, USA) for 1 hour at room temperature, dehydrated in serial ethanol dilutions, and embedded in paraffin blocks. Paraffin sections of $4 \mu \mathrm{m}$ thick, were stained for histological analysis with Alcian Blue 8GX solution (Sigma-Aldrich Corp, MO, USA) to demonstrate the presence of mucopolysaccharides in the extracellular matrix.

\section{RESULTS}

\section{Isolation and culture}

The mean volume of collected BM was $4.10 \mathrm{~mL}( \pm 1.36$ $\mathrm{mL}$ ) with median and mode $5.00 \mathrm{~mL}$ (range 1-6). The average of mononuclear cells was $12.29 \pm 6.05 \times 10^{6}$ cells/ $\mathrm{mL}$ (range $1.08 \times 10^{6}-25.00 \times 10^{6}$ ) and the cell viability was $93.19 \pm 10.12 \%$ (range $60.00-99.63 \%$ ) with median $95.50 \%$ and mode $99.20 \%$. The total amount of mononuclear cells collected per sample was $1.08 \times 10^{6}$ cells to $99.25 \times 10^{6} /$ bone.

The cells were expanded up to P3-P4. Feline BM-MSC showed a growth curve consisting of an exponential growth phase followed by a stationary or decreasing phase (Fig.1).

\section{Colony-forming unit for fibrobasts (CFU-F) assays}

We found heterogeneity in colony size and morphology. To evaluate clonogenic efficiency, cell clusters that formed a solitary colony were counted after 14 days of culture. The mean number of MSCs colonies after cultivation of 470 and 752 cells $/ \mathrm{cm}^{2}$ was $15.5 \pm 7.30$ and $10,25 \pm 6,25$ in P1, respectively. In $\mathrm{P} 2$, the mean number was $8.58 \pm 6.16$ and $16.26 \pm 9.25$, to each concentration.

Feline BM-MSCs were adherent, and spindle-shaped cells that proliferated to form colonies (Fig. 2).

\section{Feline BM-MSCs morphology}

We observed the predominance of two cell type: spindle-shaped and widespread cells. The spindle-shaped cells exhibited larger length, central nuclei, small cytoplasm and variable cytoplasm shape. We found spindle-shaped cells with long thin cytoplasmic processes at both ends of the cells (Fig.3A), with Y-shaped cytoplasm (Fig.3B) and smaller spindle-shaped cells with more cytoplasm at one end of the cell

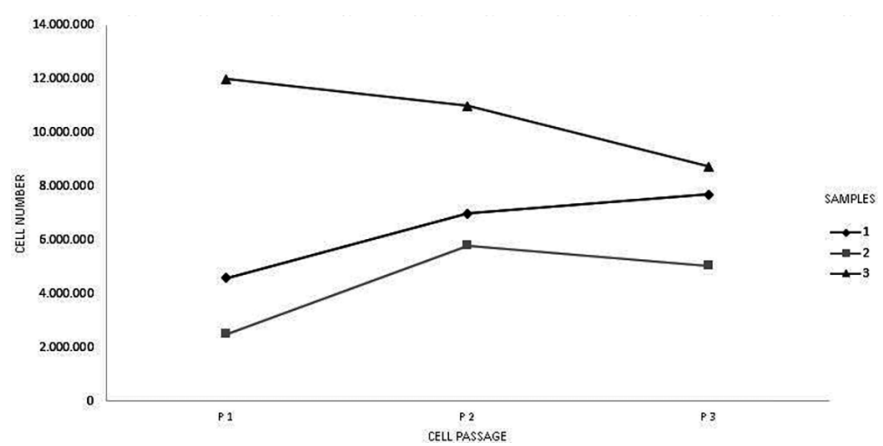

Fig.1. Growth curve of feline BM-MSCs. On the y-axis is the cell number in each passage and the $\mathrm{x}$-axis is the cell passage (P1, P2 and P3). 


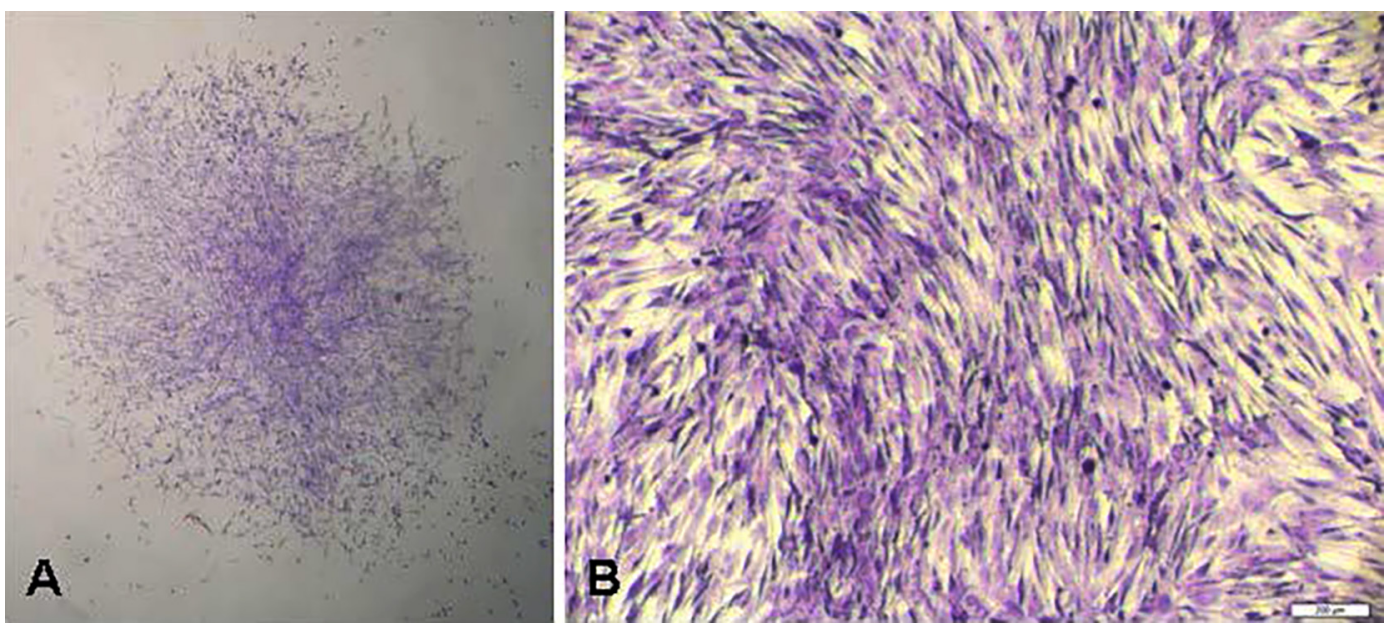

Fig.2. Colony-forming unit for fibrobasts (CFU-F) assays. Colony stained with crystal violet. (A) Colony observed under a magnifying lens, 200x. (B) Colony observed under an inverted biological microscope.

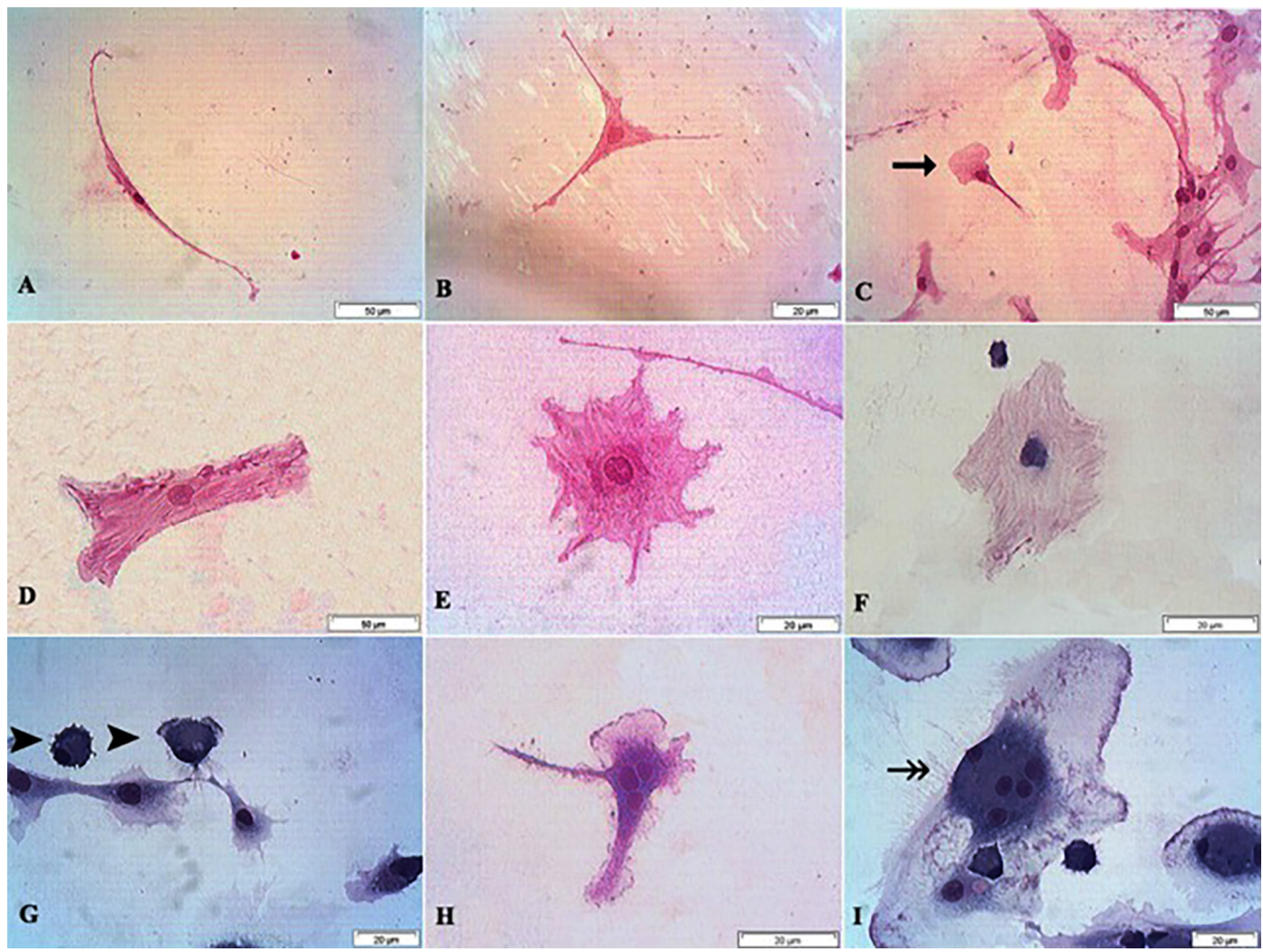

Fig.3. Cells observed in the morphologic analysis: (A) Spindle-shaped cells with long thin cytoplasmic processes at both ends of the cells, P3, 48h, 200x. (B) Spindle-shaped cells with Y-shaped cytoplasm, P3, 48h, 400x. (C) Spindle-shaped cells with more cytoplasm at one end of the cell (arrow), P3, 120h, 200x. (D) Rectangular widespread cells, P3, 120h, 200x. (E) Rounded widespread cells with abundant cytoplasm, P3, 24h, 400x. (F) Widespread cells with low cytoplasmic basophilia and intense affinity for basic dyes around nuclei, P1, 24h, 200x. (G) Smaller spherical cells with odd nuclei and intense cytoplasmic basophilia (arrowhead), P1, 48h, 400x. (H) Multi-nucleated cells, P1, 48h, 400x. (I) Osteoclasts (double arrow), P1, 120h, 400x. Wright's stain.

(Fig.3C). The widespread cells exhibited variable cytoplasm shape and affinity for dyes. We found rectangular (Fig.3D) and rounded widespread cells (Fig.3E) and, more frequently in P1, widespread cells with low cytoplasmic basophilia and intense affinity for basic dyes around nuclei (Fig.3F) and smaller spherical cells with odd nuclei and intense cytoplas- mic basophilia (Fig.3G). We also observed occasional multi-nucleated cells (Fig.3H) and some osteoclasts (Fig.3I).

\section{Feline BM-MSCs morphometry}

The results of the statistical inference of the cells measurements, in P1 and P3, were showed in Tables 1 and 2, 
Table 1. Measurements $(\mu \mathrm{m})$ of feline bone marrow MSC first passage $24,48,72$ and 120 hours of culture

\begin{tabular}{lcccc}
\hline Parameter & $24 \mathrm{~h}$ & $48 \mathrm{~h}$ & $72 \mathrm{~h}$ & $120 \mathrm{~h}$ \\
\hline Cell length & $106.97^{\mathrm{c}} \pm 38.16$ & $125.86^{\mathrm{bc}} \pm 55.15$ & $136.65^{\mathrm{b}} \pm 51.23$ & $170.51^{\mathrm{a}} \pm 66.29$ \\
Cell width & $30.79^{\mathrm{a}} \pm 16.75$ & $36.21^{\mathrm{a}} \pm 21.22$ & $31.38^{\mathrm{a}} \pm 16,04$ & $34.63^{\mathrm{a}} \pm 17.29$ \\
$\begin{array}{l}\text { Nucleus } \\
\text { length }\end{array}$ & $16.28^{\mathrm{c}} \pm 3.02$ & $17.10^{\mathrm{c}} \pm 2.61$ & $19.09^{\mathrm{b}} \pm 3.64$ & $21.29^{\mathrm{a}} \pm 4.13$ \\
$\begin{array}{l}\text { Nucleus } \\
\text { width }\end{array}$ & $11.91^{\mathrm{b}} \pm 2.37$ & $12.71^{\mathrm{ab} \pm 2.53}$ & $13.38^{\mathrm{a}} \pm 2.54$ & $13.72^{\mathrm{a}} \pm 2.47$ \\
& & & &
\end{tabular}

The equal letter indicates lack of significant difference (Tukey's test, $P<0.05$ ).

Table 2. Measurements $(\mu \mathrm{m})$ of feline bone marrow MSC third passage 24, 48, 72 and 120 hours of culture

\begin{tabular}{|c|c|c|c|c|}
\hline Parameter & $24 \mathrm{~h}$ & $48 \mathrm{~h}$ & $72 \mathrm{~h}$ & $120 \mathrm{~h}$ \\
\hline & $177.91^{\mathrm{a}} \mathrm{b} \pm 71$ & $139.72^{\mathrm{b}} \pm 54.88$ & $186.51^{\mathrm{a}} \pm 78.07$ & $210.88 a$ \\
\hline & $40.18^{\mathrm{a}} \pm 20.46$ & $36.06^{\mathrm{a}} \pm 17.81$ & $34.31^{\mathrm{a}} \pm 1$ & $39.55^{a} \pm 21.30$ \\
\hline $\begin{array}{l}\text { Nucleus } \\
\text { length }\end{array}$ & $26.35^{\mathrm{a}} \pm 3.39$ & $21.43^{c} \pm 4.03$ & $23.12^{\mathrm{bc}} \pm 5.21$ & $25.22^{\mathrm{ab}} \pm 5.83$ \\
\hline $\begin{array}{l}\text { Nucleus } \\
\text { width }\end{array}$ & $16.89^{\mathrm{a}} \pm 1.72$ & $15.21^{\mathrm{b}} \pm 3.07$ & $15.06^{\mathrm{b}} \pm 3.18$ & $16.12^{\mathrm{ab}} \pm 4.00$ \\
\hline
\end{tabular}

The equal letter indicates lack of significant difference (Tukey's test, $P<0.05$ ). respectively. Morfometric differences were reported for the feline MSCs. At first passage, cell and nucleus lengths increased between 24 and 120 hours ( $<<0.05)$, and the cell and nucleus widths also increased, however without statistical difference. At third passage, only the cell length increased between 24 and 120 hours and the cell and nucleus widths increased, however without statistical difference.

The cell lengths were $106.97 \pm 38.16 \mu \mathrm{m}$ and 177.91 $\pm 71.61 \mu \mathrm{m}$, respectively, at first and third passages $(24 \mathrm{~h})$. The cell width at first passage $(24 \mathrm{~h})$ was $30.79 \pm 16.75 \mu \mathrm{m}$ and this measurement at third passage $(24 \mathrm{~h})$ was $40.18 \pm 20.46 \mu \mathrm{m}$. The nucleus length of the feline BM-MSCs at P1 increased from $16.28 \mu \mathrm{m}(24 \mathrm{~h})$ to $21.29 \mu \mathrm{m}(120 \mathrm{~h})$. However, at P3, the nucleus length was $26.35 \mu \mathrm{m}$ (24h) and $25.22 \mu \mathrm{m} \mathrm{120h).}$

\section{Differentiation of feline BM-MSCs}

The feline BM-MSCs isolated were differentiated into three mesodermal lineages adipogenic, osteogenic, and chondrogenic (Fig.4). Adipogenic differentiation of feline BM-MSCs was demonstrated by the intracellular accumulation of lipid droplets (Fig.4A). Osteogenic differentiation of marrow-derived stem cells over a period of 21 days was

Fig.4. Feline bone marrow mesenchymal stem cells differentiation. (A) Lipid-rich cytoplasmic vacuoles (arrow) stained with Oil Red 0. (B) Mineralization of the extracellular matrix (arrow) stained with Alizarin Red S. (C) Matrix proteoglycans and lacunaes (arrow) stained with toluidine blue. (D-F) Untreated control cultures without adipogenic, osteogenic or chondrogenic differentiation stimuli are shown on the right side.

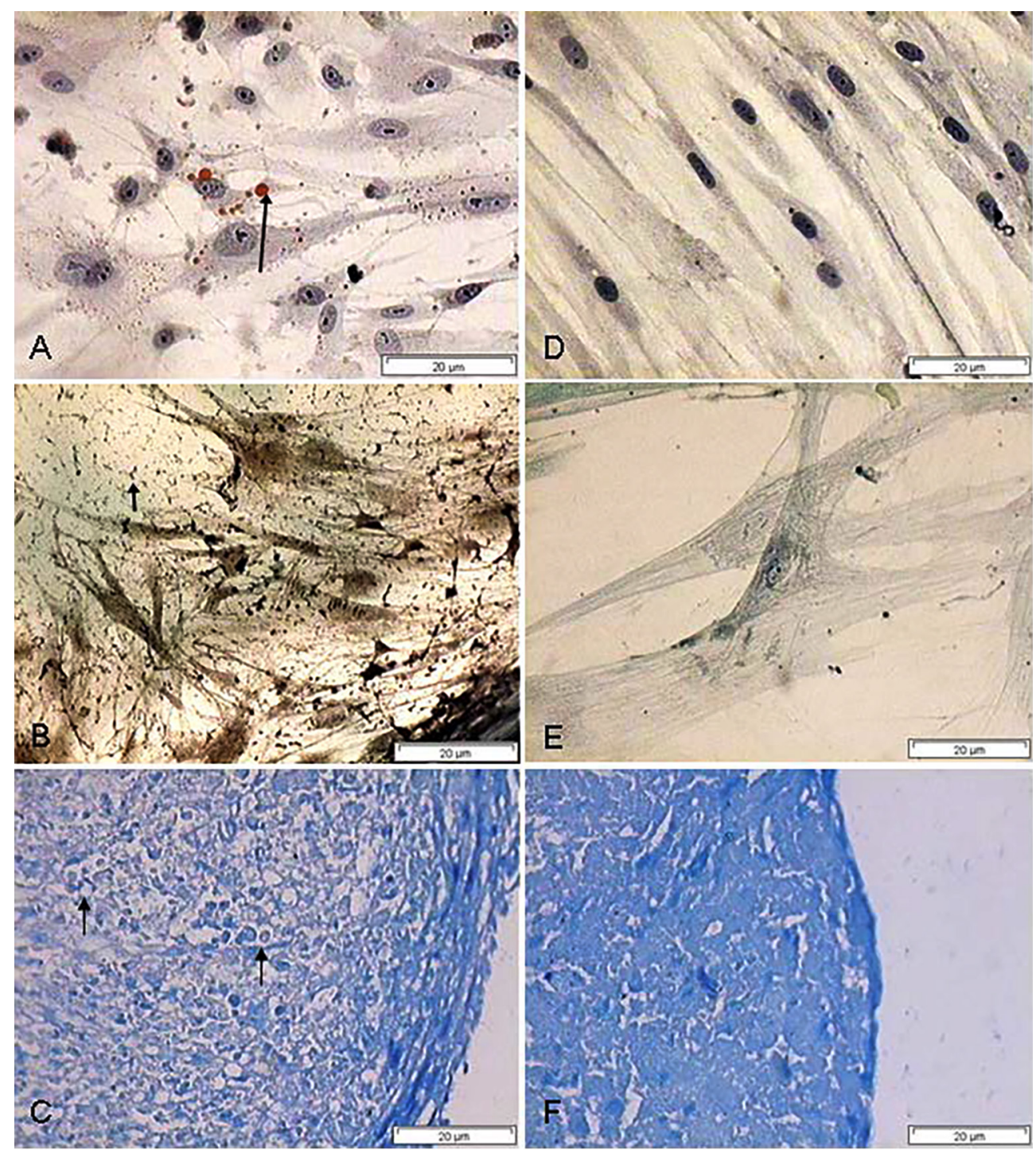


demonstrated by the formation of mineralised tissue. The mineral was stained with Alizarina Red S (Fig. 4B). In chondrogenic differentiation, BM-MSCs formed aggregates that dislodged, floating freely in the suspension culture. High-density micromass MSCs cultures generated cellular nodules, which produced large amounts of cartilage-related extra-cellular matrix molecules like collagen. The cells stained positively for Toluidine Blue; this dye is specific for the highly sulfated proteoglycans of cartilage matrices. (Fig 4C).

\section{DISCUSSION}

This study has demonstrated the isolation of adult feline BM-MSC, proliferation potential and differentiation into three lineages. Although some studies have been demonstrated the in vitro potential of feline BM-MSCs for tissue regeneration (Jin et al., 2008; Quimb et al., 2011), and immunogenecity (Martin et al. 2002, Zhang et al. 2011), most of them lacked in vitro morfometry analysis.

With the protocol of cell isolation used in this study, it was obtained the average mononuclear cells of 12.29 $\pm 6.05 \times 10^{6}$ cells $/ \mathrm{mL}$. The total amount of mononuclear cells collected per sample was $1.08 \times 10^{6}$ cells to $99.25 \times 10^{6} /$ bone. The number of cells was lower compared to the study of Martin et al., 2002. They isolated feline BM-MSCs and the total amount of marrow cells collected per bone ranged from $4.25 \times 10^{8}$ to $1.13 \times 10^{9}$. In human patients, the average total mononuclear cells recovered from the BM in pediatric patients was $2.1 \times 10^{6} / \mathrm{mL}$ and in older patients was $3.2 \times 10^{6} / \mathrm{mL}$ (Harting et al. 2009).

To evaluate the growth curve of feline BM-MSC, cells were harvested and counted in passage 1, 2 and 3. It was observed that, after P3, there is a decrease in cell growth. This loss of proliferation probably occurred because cellular senescence. Similarly, Cheng et al. (2012) showed that MSC derived from mouse BM could be propagated until passage five, demonstrating a low proliferative potential of these cells. Although there is a decrease of cell proliferation rate at P3-4, these cells retained the differentiation potential. Munoz et al. (2013) demonstrated that cell age may not be a crucial factor in affecting differentiation ability in feline BM-MSC.

The gold standard assay utilized to determine feline BM-MSCs frequency is the colony-forming unit for fibrobasts (CFU-F) assay (Baksh et al. 2004). In our study, we showed that feline BM-MSC exhibited colony-forming ability, although the number of colonies seems to be less than that observed in human MSC cultures derived from different sources (Avanzini et al. 2009, Kurt Yüksel, et al. 2010, Tamaki et al. 2012). The lower values obtained with CFU-F assay for cultures plated at the higher density as observed in P1 in our study, are consistent with previous observations that cultures plated at higher density show a rapid decrease in the number of multipotential and rapidly self-renewing cell (Javazon et al. 2001).

Comparison of results obtained from CFU-F determination assays in several studies is difficult, because plating density is not constant. In fact, the optimal plating density has not yet been defined in the literature (Javazon et al. 2001). Croft \& Przyborski (2004) reported that, when plated at a low density of approximatelly $3 \mathrm{cell} / \mathrm{cm}^{2}$, a proliferation of small recycling stem cells appeared to be most multipotent cells in the culture. However, Carlo-Stella \& Gianni (2005) emphasized that, because MSC survive with the help of their own autocrine or paracrine factors, they show apoptosis without colony formation in low-number cell densities. In addition, the number of CFU-F colonies in normal BM is not known exactly (Suzuki et al. 2001, Kurt Yüksel et al. 2010). Wellman \& Kociba (1988) reported that the mean CFU-F per $10^{6}$ mononuclear cells in bone marrow from healthy kittens and adult cats was 62 and 65, respectively. The authors also observed that variation in the feline CFU-F assay was similar to that reported for the human CFU-F assay.

Furthermore, the criteria for the definition of a CFU-F colony are somewhat different in the literature; 20 or 50 cells have been used as the diagnostic threshold (Koller et al. 1998).

Samples of feline BM-MSCs generated plastic-adherent, spindle-shaped cells when maintained in standard culture conditions. Plastic adherence is a well-described property of MSC (Dominici et al. 2006), and subsets of feline BM-MSCs have been maintained this property.

Feline MSCs exhibit two distinct morphologies: spindle-shaped cells with long thin cytoplasmic processes at both ends and spindle-shaped cells with more cytoplasm at one end of the cell. Rectangular widespread cells and rounded widespread cells with abundant cytoplasm were also observed at 3 passage. As reported by previous investigators, human and equine MSC cultures also exhibit distinct morphologies (De Schauwer et al. 2011). De Schauwer et al. (2011) reported that equine MSCs showed a varying cellular morphology, from very slender and elongated towards more cuboidal with shorter cytoplasmatic extension, as observed for feline MSCs. In 2002, Martin et al. described the feline BM-MSC as fibroblast-like, appearing polygonal or spindle-shaped with long process (Martin et al. 2002). Webb et al. (2011) reported that samples of feline bone marrow and adipose tissue also generated plastic adherent, spindle-shaped cells. According with previously studies, MSCs can be assigned to at least two morphological types: rapidly self-renewing, small, round or spindle-shaped cells (RS cells) and slowly replicating, large, cuboidal or flattened cells (mature MSCs). Furthermore, RS cells manifested the highest multipotentiality (Docheva et al. 2008).

Additionally, multinucleated cells were also observed in feline marrow cultures after 120 hours, and these cells have many of the characteristics of osteoclasts (large and multinucleated). Kenneth et al. (1984) observed that multinucleated cells form in feline marrow cultures within $48 \mathrm{~h}$, reaching maximum numbers at 16 days, and demonstrated that these multinucleated cells in long-term feline marrow cultures have ultrastructural features of osteoclasts.

Currently, there is no information about the morphometry of feline MSCs generated from cats. The present study investigated the morphometric properties of the feline BM-MSCs at P1 and P3 (24, 48, 72 and 120h of culture). All of the cultures contained a large proportion of spindle-shaped cells, and an image analyzing program was used to 
measure cell and nucleus areas of cells in the cultures. Morfometric differences were reported for the feline MSCs. At first passage, cell and nucleus lengths increased between 24 and 120 hours $(\mathrm{p}<0.05)$, and the cell and nucleus widths also increased, however without statistical difference. At third passage, only the cell length increased between 24 and 120 hours and the cell and nucleus widths increased, however without statistical difference. The cell width at first passage (24h) was $30.79 \pm 16.75 \mu \mathrm{m}$ and this measurement at third passage $(24 \mathrm{~h})$ was $40.18 \pm 20.46 \mu \mathrm{m}$, possibly because with later-passage cells, large and flat cells (MSCs) appeared. The maximal widths of the human MSCs were progressively greater between day 4 and day 6 and between day 6 and day 10 (Sekiya et al. 2002). Cultures of feline MSCs cultures undergo changes as they are expanded, as observed in cultures of human MSCs (Sekiya et al. 2002m Docheva et al. 2008).

In the present study, the nucleus length of the feline BM-MSCs at P1 increased from $16.28 \mu \mathrm{m}(24 \mathrm{~h})$ to $21.29 \mu \mathrm{m}$ (120h). However, at P3, the nucleus length was $26.35 \mu \mathrm{m}$ $(24 \mathrm{~h})$ and $25.22 \mu \mathrm{m} \mathrm{120h})$. The nucleus lengths of the dog and horse AD-MSCs were $16.2 \mu \mathrm{m}$, and $16.4 \mu \mathrm{m}$, respectively (Grzesiak et al. 2011). According to Grzesiak et al. (2011), morphology and morphometry of equine and canine adipose derived mesenchymal stem cells (AD-MSCs) in culture tend to be very similar, however further studies of this topic are needed. Hoogduijn et al. (2013) compared the morphology and size of mesenchymal stem cells (AD-MSCs) from two mammals of noticeably different body size (mouse and whale). The average diameter of 50 mesenchymal stem cells from the mouse and 50 from the whale was 28 (SD 0.86) $\mu \mathrm{m}$ and $29(0.71) \mu \mathrm{m}$, respectively. The mesenchymal stem cells from mouse and whale are of equal morphology and size in culture (Hoogduijn et al. 2013). Docheva et al. (2008) compared the topographic and morphometric features of rapidly self-renewing cells (RS) and flat cells (FC), human osteoblasts (OBs) and MG63 osteosarcoma cells by atomic force microscopy (AFM). In the present study a homogeneous population of culture feline cells was measured, however, future studies could investigate the morphological and morphometric characteristics of different feline MSCs types.

Consistent with earlier studies, feline MSCs were capable of undergoing differentiation into osteoblasts, adipocytes and chondroblasts in vitro. Another studies reported that feline MSC derived from BM, adipose tissue, and umbilical cord blood can be induced to differentiate towards osteogenesis, chondrogenesis, and adipogenesis (Webb et al. 211, Quimb et al. 2011). In addition, neuronal and myogenic differentiation potential has also been reported for feline MSC (Martin et al. 2002, Jin et al. 2008. Kubo et al. 2009, Zhang et al. 2011, Munoz et al. 2012). The immunophenotypic characterization of feline MSCs was earlier performed using flow cytometry (Martin et al. 2002, Webb et al. 2011).

\section{REFERENCES}

Avanzini M.A., Bernardo M.E., Cometa A.M., Peroti C., Zaffaroni N., Novara F., Visai L., Moretta A., Del Fante C., Villa R., Ball L.M., Fibbe W.E., Maccario R. \& Locatelli F. 2009. Generation of mesenchymal stromal cells in the presence of platelet lysate: a phenotypic and functional comparison of umbilical cord blood- and bone marrow derived progenitors. Haematologica 94:1649-1660.

Baksh D., Song L. \& Tuan R.S. 2004. Adult mesenchymal stem cells: characterization, differentiation, and application in cell and gene therapy. J. Cell Mol. Med. 8(3):301-316.

Cheng C.C., Lian W.S., Hsiao F.S., Liu I.H., Lin S.P., Lee Y.H., Chang C.C., Xiao G.Y., Huang H.Y., Cheng C.F., Cheng W.T. \& Wu S.C. 2012. Isolation and characterization of novel murine epiphysis derived mesenchymal stem cells. PLoS One 7:360-385.

Croft A.P. \& Przyborski S.A. 2004. Mesenchymal stem cells from the bone marrow stroma: basic biology and potential for cell therapy. Curt. Anaesth. Crit. Care 15:410-417.

Carlo-Stella C. \& Gianni M.A. 2005. Biology and clinical applications of marrow mesenchymal stem cells. Pathol. Biol. 53:162-64.

Docheva D., Padula D., Popov C., Mutschler W., Clausen-Schaumann H. \& Schieker M.J. 2008. Researching into the cellular shape, volume and elasticity of mesenchymal stem cells, osteoblasts and osteosarcoma cells by atomic force microscopy. J. Cell Mol. Med. 12(2):537-552.

De Schauwer C., Meyer E., Van de Walle G. \& Van Soom A. 2011. Markers of stemness in equine mesenchymal stem cells: a plea for uniformity. Theriogenology 75:1431-1443.

Dominici M., Le Blanc K., Mueller I., Slaper-Cortenbach I., Marini F.C., Krause D.S., Deans R.J., Keating A., Prockop D.J. \& Horwitz E.M. 2006. Minimal criteria for defining multipotent mesenchymal stromal cells: the International Society for Cellular Therapy position statement. Cytotherapy 8:315-317.

Fortier L.A. \& Travis A. J. 2011. Stem cells in veterinary medicine. Stem Cell Res. Ther. 2(9):1-5.

Grzesiak J., Marycz K., Czogala J., Wrzeszcz K. \& Nicpon J. 2011. Comparison of behavior, morphology and morphometry of equine and canine adipose derived mesenchymal stem cells in culture. Int. J. Morphol. 29(3):1012-1017.

Harting M.T., Cox C.S., Day M.C., Walker P., Gee A., Brenneman M.M., Grotta J.C. \& Savitz S.I. 2009. Bone marrow-derived mononuclear cell populations in pediatric and adult patients. Cytotherapy 11(4):480-484.

Javazon E.H., Colter D.C., Schwarz E.J. \& Prockop D.J. 2001. Rat marrow stromal cells are more sensitive to plating density and expand more rapidly from single-cell-derived colonies than human marrow stromal cells. Stem Cells 19:219-225.

Jin G.Z., Yin X.J. \& Yu X.F. 2008. Generation of neuronal-like cells from umbilical cord blood-derived mesenchymal stem cells of a RFP-transgenic cloned cat. J. Vet. Med. Sci. 70:723-726.

Kenneth J., Ibbotson G., Roodman D., McManus L.M. \& Mundy G.R. 1984. Identification and characterization of osteoclast-like cells and their progenitors in cultures of feline marrow mononuclear cells. J. Cell Biol. 99:471-480

Koller M.R., Palsson M.A., Manchel I., Maher R.J. \& Palsson B.O. 1998. Tissue culture surface characteristics influence the expansion of human bone marrow cells. Biomaterials 19:1963-1972.

Kubo H., Berretta R.M. \& Jaleel N. 2009. c-Kit+ bone marrow stem cells differentiate into functional cardiac myocytes. Clin. Transl. Sci. 2:26-32.

Kurt Y.M., Topçuoglu P., Kurdal M. \& Ilhan O. 2010. The clonogenic potential of hematopoietic stem cells and mesenchymal stromal cells in various hematologic diseases: a pilot study. Cytotherapy 12:38-44.

Martin D.R., Cox N.R., Hathcock T.L., Niemeyer G.P. \& Baker H.J. 2002. Isolation and characterization of multipotential mesenchymal stem cells from feline bone marrow. Exp. Hematol. 30:879-886.

Meirelles L.S. \& Nardi N.B. 2003. Murine marrow-derived mesenchymal stem cell: isolation, in vitro expansion, and characterization. Brit. J. Haematol. 123:702-711.

Munoz J.L., Greco S.J., Patel S.A., Sherman L.S., Bhatt S., Bhatt R.S., Shrensel J.A., Guan Y.Z., Xie G., Ye J.H., Rameshwar P. \& Siegel A. 2012. Feline bone marrow-derived mesenchymal stromal cells (MSCs) show similar phenotype and functions with regards to neuronal differentiation as human MSCs. Differentiation 84:214-222. 
Penha E.M., Meira C.S., Guimarães E.T., Mendonça M.V.P., Gravely F.A., Pinheiro, C.M.B., Pinheiro T.M.B., Barrouin-Melo S.M., Ribeiro-dos-Santos R. \& Soares M.B.P. 2014. Use of autologous mesenchymal stem cells derived from bone marrow for the treatment of naturally injured spinal cord in dogs. Stem Cells Int. 2014:1-8.

Quimby J.M., Webb T.L., Gibbons D.S. \& Dow S.W. 2011. Evaluation of intrarenal mesenchymal stem cell injection for treatment of chronic kidney disease in cats: a pilot study. J. Feline Med. Surg. 13:418-426.

Rebelatto C.K., Aguiar A.M., Moretao M.P., Senegaglia A.C., Hansen P., Barchiki F., Oliveira J., Martins J., Kuligovski C., Mansur F., Christofis A., Amaral V.F., Brofman P.S., Goldenberg S., Nakao L.S. \& Correa A. 2008. Dissimilar differentiation of mesenchymal stem cells from bone marrow, umbilical cord blood, and adipose tissue. Exp. Biol. Med. 233:901913.

Sekiya I., Larson B.L., Smith J., Pochampally R., Cui J. \& Prockop D.J. 2002. Expansion of human adult stem cells from bone marrow stroma: conditions that maximize the yields of early progenitors and evaluate their quality. Stem Cells 20:530-554.

Shah F.S., Wu X., Dietrich M., Rood J. \& Gimble J.M. 2013. A non-enzymatic method for isolating human adipose tissue-derived stromal cells. Cytotherapy 15(8):979-85.

Suzuki Y., Kim K.J., Kotake S. \& Itoh T. 2001. Stromal cell activity in bone marrow from the tibia and iliac crest of patients with rheumatoid arthritis. J Bone Miner. Metab. 19:56-60.

Tamaki Y., Nakahara T., Ishikawa H. \& Sato S. 2013. In vitro analysis of mesenchymal stem cells derived from human teeth and bone marrow. Odontology 101:121-132.

Webb T.L., Quimby J.M. \& Dow S.W. 2012. In vitro comparison of feline bone marrow-derived and adipose tissue-derived mesenchymal stem cells. J. Feline Med. Surg. 14:165-168.

Wellman M.L. \& Kociba G.J. 1988. Characterization of fibroblast colony-forming units in bone marrow from healthy cats. Am. J. Vet. Res. 49:231-235

Zhang Z., Maiman D.J., Kurpad S.N., Crowe M.J. \& Alexanian A.R. 2011. Feline bone marrow-derived mesenchymal stem cells express several pluripotent and neural markers and easily turn into neural-like cells by manipulation with chromatin modifying agents and neural inducing factors. Cell Reprog. 13(5):385-390. 